\title{
Women, gender and power among indigenous peoples of Portuguese Timor
}

Women, gender and power among indigenous peoples of Portuguese Timor

\section{Kelly Cristiane da Silva}

\section{(2) OpenEdition \\ 12 Journals}

Edição electrónica

URL: https://journals.openedition.org/aa/2240

DOI: $10.4000 / a a .2240$

ISSN: 2357-738X

Editora

Programa de Pós-Graduação em Antropologia Social (UnB)

\section{Edição impressa}

Data de publição: 1 dezembro 2017

Paginação: 183-205

ISSN: 0102-4302

\section{Refêrencia eletrónica}

Kelly Cristiane da Silva, «Women, gender and power among indigenous peoples of Portuguese Timor», Anuário Antropológico [Online], v.42 n.2 | 2017, posto online no dia 12 junho 2018, consultado o 18 maio 2021. URL: http://journals.openedition.org/aa/2240 ; DOI: https://doi.org/10.4000/aa.2240

\section{(c) (i) (9)}

Anuário Antropológico is licensed under a Creative Commons Atribuição-Uso Não-Comercial-Proibição de realização de Obras Derivadas 4.0 International. 


\title{
Women, gender and power among indigenous peoples of Portuguese Timor ${ }^{1}$
}

\author{
For Mariza Corrêa, in memoriam \\ Kelly Cristiane da Silva
}

UnB

My purpose is to discuss some aspects of women's condition and the influence of gender classifications on indigenous peoples in Portuguese Timor from 1945 to 1975. This bibliographic essay focuses on discourses from two distinct fields. One is anthropology, which, as of the 1960s, produced a wealth of information about the dynamics of social reproduction among the peoples of East Timor. The other is the field of missionary and colonial knowledge, whose texts were aimed at governing colonial subjects most efficiently. ${ }^{2}$ Although I focus on anthropological studies about the peoples who lived in what was then Portuguese Timor, I also use works about other populations of the region, for example, in West Timor and other islands in Eastern Indonesia, as well as texts on earlier periods. I argue that, from the local point of view, women held a relatively subaltern position regarding the higher and collective dynamics of social reproduction, such as lifecycle rituals, conflict resolution processes, marriages, etc.

On the one hand, this situation resulted from the way the local social structure was arranged, taking the house as a sacred and immutable male descent group. Male dominance prevailed even in matrilineal groups with houses descended from women, because men controlled the access and management of their symbolic reproduction, like the ritual knowledge about fertility and the relationship with ancestors. Hence, male dominance in the collective spaces of different societies resulted from their monopoly not only of the means of symbolic reproduction, but also of the relative downgrading of female activities in that field, except for Caraubalo Tetum women (Hicks, 1984). The Catholic Church in Portuguese Timor provided schooling and other types of instruction for women with the apparent purpose of producing European-style wives, skilled in the domestic duties but strictly limited to household and private realm, which was, in turn, viewed as inferior to collective spaces. ${ }^{3}$

On the other hand, however, the sources suggest that the women's power increased as they aged and actively managed life in locally less important domains, such as the domestic space and in market or barter exchanges. Women were still central to the dynamics of material reproduction, sharing with men tasks related 
to agriculture. Based on this information, we can see that their conditions were multiple, depending on the social space we select for analysis. Women's status depends on a number of factors, such as age, schooling and the position of her house in the local hierarchy. As a counterpoint, male dominance in collective spaces did not derive exclusively from their gender, but also from other markers of social differentiation, such as age, membership in specific clans and houses, personal skills, etc.

Despite the socially and politically subaltern condition of women in collective spaces, many Timor-Leste peoples honored femaleness as a classifying principle related to the house, the inner world, the sacred and the reproductive potential of women. Much ritual and social investment was made to activate, assess and reproduce femaleness and its powers, following an ethic of reciprocity. Nevertheless, the ritual knowledge and techniques used in these rituals were mostly controlled by men from specific houses. Hence, inspired by Ortner (1974) and Rubin (1975), among other feminist anthropologists, and by Godelier (1982), I suggest that an important part of the ritual life among various peoples in Portuguese Timor invested men with potencies/powers associated to femaleness, namely, fertility and collective reproduction. An important consequence of this is that the monopoly women might have on femaleness was dissolved. Femaleness thus gained autonomy and could be deployed by other agents in different contexts. It is, therefore, crucial to detach biological sex from gender if we are to understand how the dynamics of social reproduction were negotiated in that part of the world. ${ }^{4}$

\section{Methodological mediations}

As a guide to reading the analyses that follow, some methodological mediations are in order. In the first place, I draw information from fields based on distinct epistemological premises. Anthropological knowledge has followed a relativist, contextual and empirical path. In contrast, missionary knowledge often exposed ethnocentric positions and the intention to promote social changes towards bringing local peoples close to the European ideal of sociability, or to serve colonial interests and projects of social reproduction.

Greater analytical rigour would require that I limited my sources to one of these fields of knowledge or shorten the time span of my analysis. However, the scarcity of works addressing my specific interest leads me to risk handling these different sources, in the hope of stimulating further questions to be more thoroughly answered in the future. 
It is impossible to do a unifying and totalizing analysis of women's conditions in post-World War II Portuguese Timor. As we know, various peoples have lived on the sociopolitical borders of Timor-Leste for a long time, holding on to their own cosmologies and social organisation dynamics. Moreover, the colonial encounter produced new modes of social distinction as, for instance, the difference between women who studied in colonial schools and those who had no access to them. Therefore, I shall alternate between broad issues about women's conditions and gender classifications and specificities, such as place, origin and age.

I should also point out that the anthropological literature on the peoples and regions of Portuguese Timor from the 1960 onward focused on the analysis of symbolic and classification systems and their ritual use. Not much was written about women's roles in material reproduction, political dynamics, etc., although gender dualism appears in many of the works cited here. This affects my analyses, because I had to deduce certain structural relations from their residual place in the ethnographies. Thus, I ask the reader to bear with me and take this essay as a tentative effort with no aim to be conclusive.

Neither in anthropological texts nor in colonial and missionary discourses could I identify how women saw themselves in the social dynamics that involved them. In the case of structuralist anthropology, this may be due to the theoretical issues that guided research - emphasis on classification systems, social organisation and ritual - and, it seems to me, to the fact that many of the anthropologists' interlocutors were men. In the missionary texts this gap apparently reflects, at least in part, the male profile of their sources, as well as a projection of the missionaries' political and epistemological anxieties.

Considering all these mediations, this text solely addresses women positions in the dynamics of collective social reproduction where male dominance is recognised. Hence, we cannot infer from these analyses that women, generally and thoroughly, lacked agency or any kind of dominance. According to Strathern (1987), agency and effective action have to do with the way people allocate causality and responsibility to each other. From the viewpoint of anthropology, to ask about agency also presumes that industrial societies understand it as productive transformation and resource (human and non-human) domestication to alter (rather than restore) the world toward certain ends. Bearing in mind the important theoretical advances set off in the past decades by the dialogue between anthropology and feminism (Mckinnon 1991; Ortner, 1974; Strathern, 1987, 1988), we need to critically raise questions such as these: how do people devise the experience of power holding? How do different people formulate projects in which their actions affect the world they live in? 
This text is organized in four sections and final considerations. In the first section, I take women's subalternity in collective spaces as the result of the broader dynamics of social organisation and reproduction of their groups of origin (houses). I then discuss the issue of marriage prestations and their effects on a woman's status. In the third section, the most complex and abstract one, I show how rituals of collective reproduction endow men with fertility powers and how they empower themselves in the women's eyes. This section tries to elucidate the apparent contradiction between the fact that, among many Timor-Leste peoples, femaleness, as a gender classifying principle, is associated with superiority and, at the same time, women are often in a subaltern position vis-à-vis collective reproduction. I argue that the way the female principle and the idea of fertility are ritually handled serve the purpose of producing and reproducing male dominance in collective social reproduction. Finally, I address the efforts of the Catholic Church to produce Christian women. As discussed by Cristalis and Scott (2005), I argue that they reinforced the confinement of women to the domestic space.

\section{Women in men's houses: the structural effect of subalternity}

For an adequate understanding of women's condition in Portuguese Timor, we must locate them within the institutions where they lived. The features of these institutions and their modes of reproduction partially explain the positions attributed to women, as well as the ways they exerted their agency and resistance to those structures. Thus, the following discussion prioritizes the analysis of the pattern the local social institutions took, to better understand the ascription of women's position. I suggest that women's subalternity in collective spaces stemmed from the mechanisms of social organisation and reproduction.

The peoples who inhabit the sociopolitical frontiers known today as TimorLeste have long been organized in houses. The house embodies a group of origin organized as a moral-religious community oriented towards ancestral cults and endowed with material (ancestral relics) and immaterial (knowledge and ritual) assets. It is a basic membership unit, which in patrilineal societies comprises a group of people who think of themselves as descended from men. Besides its ritual and religious role, the house is an institution that regulates property, work, consumption, belonging, power, etc. The house produces or combines several other dimensions of social organisation (Carsten \& Hugh-Jones, 1995; Fox, 1980, 1996; Lévi-Strauss, 1983; Traube, 1987).

With patrilineal filiation, the houses are male corporations. In most cases, women have no rights to inheritance, lest the group's property gets fragmented (Goody, 1973). The house being defined as a male group of origin, women born 
in it are not considered as full members. Though women grow up, are fed and cared for in these groups, they occupy a liminal position, given the expectation that they will enter other houses when they marry. It seems, then, reasonable to suppose that, in patrilineal regimes of social organisation and reproduction, women held a minor position because they were neither full members, as men were in their own group of origin, nor in the houses they entered after marriage. To the contrary, they seemed to be regarded as resources for production and biological/ social reproduction of and between the houses. These houses are thought of as perennial, immutable and immortal institutions. ${ }^{5}$

Hicks (1984), however, gives us a distinct interpretation of the Caraubalo Tetum case. Among them, female liminality empowered women ritually, lifting them to the position of primary mediators between her husband's house and certain spiritual entities. It was this liminal condition that qualified them to handle relationships with liminal beings or situations, such as the spirits of the upper world. I shall return to this issue.

The transient house membership of the women partly explains why, in many documented cases, they did not lead public rituals to reproduce life and propitiate the ancestors, although life reproduction is strongly tied to female fertility (Friedberg, 1989; Hicks, 2004; Nogueira, 2014; Traube, 1987). Ritual knowledge is immemorial, a powerful legacy of the ancestors, and only certain high-ranking or special people could acquire it. It could not be transmitted to members of other houses, including women (Nogueira 2014). Men's monopoly of ritual knowledge, then, adhered tightly to the way the house - the elementary unit of collective social organisation - was conceived and reproduced among most peoples in Timor-Leste. Let us remember the outstanding role of rituals in the moral reproduction of Timor-Leste peoples. I shall come back to this point below.

Added to these facts are cosmological precepts that link sexual dimorphism to gender representations and to certain moral hierarchies. Analyses by Fox (1980, 1996), McKinnon (1991), and Hoskins (2004) identified how ideas of origin and ancestry represent moral values, which, in turn, mark hierarchies between persons and peoples in Eastern Indonesia. Women of value (as opposed to slaves) are women with an origin; high ranking houses are the closest to those mentioned in mythical origin narratives. Immobility and permanence are sources of social prestige as opposed to the mobility characteristic of the women's trajectory along their life cycles. In other words, steadiness and permanence being higher moral values, by opposition, transience, classified as feminine, is morally diminished. Writing about the Tanimbar Islands to the east of Timor-Leste, McKinnon (1991) shows that gender classification is a way to identify who belongs or not 
to a house. Relative movement or stability is a consideration to define someone as male or female. Anything which circulates through the houses is feminine, including men: a woman given in marriage to another house is feminine, as is a man who was adopted to maintain the continuity of a house. Thus, women and femaleness evoke dispersal and reproduction, whereas men and maleness indicate fixedness. Whereas men are the source, women are the product of the source. Relics and the house's material wealth are masculine, because they epitomize the house's permanence (McKinnon, 1991:96).

The houses do not follow egalitarian lines. They stand asymmetrically to each other (due to their position either as wife-givers or wife-takers), ranked by origin and antiquity (Van Wouden, 1968). Relations of precedence command a series of rights and duties connected, for example, to ritual management, land tenure and processes of conflict resolution. The ranking of houses also affects the power positions of women, in such a way that those belonging to low ranking houses are potentially more vulnerable than those belonging to houses, for instance, with alleged jural and ritual powers.

As a counterpoint, Kammen (2012:150) reports a large number of women who acted as queens in nineteenth-century Portuguese Timor. According to him, as much as twenty-five percent of kingdoms under Portuguese sovereignty were then ruled by women. He attributes this state of affairs to the weakness of the colonial power in Timor at that time; to assert itself, it would have promoted certain women to the position of queens as the outcome of marriage arrangements steered to the interests of the Portuguese crown. At any rate, Kammen brings out strong cases that confirm the possibility of combining and reproducing various forms of local social organisation under the jural and political leadership of women.

Also central to the way the houses depict and reproduce themselves and narrate their trajectories are the exchanges between them, which lead to the sealing of alliances be they wife-givers or wife-takers (Van Woden, 1968). Let us remember that, apart from exceptional situations, the members of a house must marry members of another house, as the house is the basic exogamic unit. Indeed, one of the house features that qualify it as a specific form of social organisation is the equally important position of their descent and alliance relationships. For no other reason, marriages and their attendant marriage prestations, which seal inter-group alliances, are central among the practices of a house's social reproduction. Given the rule of exogamy, marriage is the conduit a house has to access a woman's reproductive potential and labor force, as essential assets for its social and biological reproduction. According to McKinnon (1991), in Tanimbar, the house becomes a male descent group by exporting its own women 
and feminine potential and importing the equivalent from other houses, as it is common in the region. Thus, marriage exchanges provide the means for a house to remove or expel female potential in the form of woman and then take fertility back from other houses, by means of other marriages. McKinnon (1991) stresses that women's ties to their houses of origin were never totally severed, especially in their fertile life-cycle, for life emanates from their origin groups. Marriage and marriage exchanges were then vital to the flow of life (Fox, 1980). Life transmission and reproduction come from the circulation of women among the houses (for a feminist critique of this, see Niner, 2012).

\section{The feminine as a power and classificatory principle; its connection to men and women: conjunctions, disjunctions and mediations}

Many anthropological studies in the late 1960s and mid-1970s observed that, in Portuguese Timor, the opposition masculine/feminine as a classificatory principle was used to structure modes of understanding, organizing and feeling the world. These studies also showed that social spheres and practices classified as feminine were superior to the masculine. Masculine and feminine as classification principles and markers of social differentiation entailed both equilibrium and asymmetrical complementarity, as one side - the feminine was superior to the other.

The superiority of the feminine seems in part to come from the fact that social reproduction is often imagined as fertilization or activation of fertility, similar to what Strathern (1984) found among the Hagen of Papua New Guinea. To several Timor-Leste peoples, the capacity of a woman or the female body to reproduce biologically sustains the idea that the feminine principle is the major trigger of social reproduction, which in turn is based, at least in part, on biological reproduction. It is not by chance that, for a long time, an important part of the social reproduction in Timor-Leste has involved the exchange of women between houses. This process is central to the flow of life (Fox, 1980), both in the social and biological sense, given the obligations and relationships it engenders.

Based on a sixteen-month fieldwork, between 1966 and 1967, among the Caraubalo Tetum, Viqueque District, Hicks (2004) suggests that their reproduction and regeneration rituals deployed fertility agents and principles from the world of the ancestors and Mother Earth. Women were closer to Mother Earth because both are female. This is why women presided over many rituals (Hicks, 1984). Female principles and forces could better mobilize entities responsible for social reproduction, ancestor spirits and Mother Earth herself. Such feminine potency came from the woman's capacity for biological reproduction. 
The association the Tetum-speaking people make between femininity and the sacred in their religion inclines towards assigning the female gender a conjunctive role in life, one in which nurturing is fundamental. The female gender is treated as though it brings fertile entities together. Men, on the other hand, are inclined towards ritual roles that lend themselves to disjunctive purposes, as in separating the dead from the living [...]. This gender contrast is given more complexity by the identification of men with secular (saun) concerns, as in political authority, rather than with sacred or spiritual (lulik) matters.

Women, in particular, mediate between human beings and spirits, a relationship that reproduces and nurtures life as it contributes to the indigenous definition of womanhood (Hicks, 2004:2).

However, symbolically, people perceived social reproduction as the result of the cooperation between different parties, with male principles and forces always present (Hicks, 2004:47). In her analysis of cosmology and ritual dynamics among the Seloi/Aileu Mambai, Traube found a similar situation during her fieldwork from October 1972 to November 1974 (Traube, 1987:ix-xii). As with other peoples in Eastern Indonesia, she identified gender dualism among the Mambai. Interaction and complementation between opposites, such as masculine-feminine, insider-outsider, older-younger, religious power-political power, were the basis for social reproduction. These were cosmological categories negotiated in the course of life. Like the Caraubalo Tetum, they took the female principle to be superior.

In her analyses of the Mambai ritual dynamics, Traube indicates that these were grounded in the house, a unilineal descent group made up of men. The rituals nurtured the relationships between houses and their sources of life. They rated the quality of the houses according to their association with Father Heaven and to a series of male attributes (immutability, indestructibility, immortality, connection and division). Nevertheless, their reproduction was only possible via entities associated with Mother Earth and the female principle.

[...] The house conceived of as a line of men is both immutable and sterile; the ties that a house contracts through women are both mutable and fertile. Social life is based on a complementary balance between a static male order and a dynamic female vitality (Traube, 1987:96).

The generative capacity of the house, as the entity which produced life, had a feminine quality. This is similar to Hicks' (1984) descriptions of the Caraubalo Tetum, whose houses were associated with femaleness and the values attributed to Mother Earth, namely, heat, darkness, protected space, and interior. The houses and their qualities respond for human conception and nourishment. Speaking of a Seloi Mambai house, Traube writes: 
she is the personified principle of life-giving immobility and constancy, a fixed point of orientation in a wider world of motion and change. Through its association with Mother Earth, the house assumes a manifestly maternal character (Traube, 1987:78).

For the Mambai, gender dualism also seemed to be connected to the division of jural/secular versus ritual/religious authority and power, the latter being relatively superior to the former. The higher ritual/religious power is also classified as feminine as opposed to the secular/managerial masculine power. Traube continues:

in theory, the Ritual Lord does not move from the origin place. His qualities of fixity, stability, and constancy evoke the figure of the housebound woman, and the association with the female category is reinforced by the nature of his service to the community (Traube, 1987:103).

However, when the Mambai used gender categories or the female image to express power positions, not always did they associate femaleness to higher positions. Traube (1987:108) affirms that, when ritual authorities wished to express their inability to handle jural and managerial matters and their subordination to temporal authorities in charge, they presented themselves as "women who stay home." By this they meant that they were as stupid as women, who needed to be controlled by men in the domestic space. She also indicates that statements on the superiority of ritual authorities belong to an age rather than gender idiom. Among the Seloi Mambai, people acknowledge the superiority of ritual authorities by calling them "Old Mother, Old Father" (Traube, 1987:109).

Hicks also identified the use of the female principle to express ideas of inferiority and superiority among the Tetum. He provides several examples of femaleness associated with inferiority and shows that, when related to superiority, it is never absolute and depends on the context. For instance, it is applied to common houses to evoke their inferiority vis-à-vis noble houses (Hicks, 1984:17). The sacred realm itself, usually associated with femaleness, can be inferior if evaluated against jural power (Hicks, 1984:22). Furthermore, the association the Mambai made between femaleness, interiority and the house meant that, symbolically, the house was considered a feminine domain; so, the domestic space was the proper place for women. Women must stay put in the private interior, waiting for the men's return, whereas exteriority and collective/ public space were understood as male qualities (Traube, 1987).

As we know, in controlling individual and collective life, rituals have long been used for governance purposes by Timor-Leste peoples. Through rituals and 
its appropriate and highly regulated mediations, collectivities communicate with spiritual entities via sacrifices and other forms of recognition and respect. In the past as in the present, many ritual acts attempt to compensate and nourish various spiritual entities (ancestors, Mother Earth, Father Heaven, etc.), as well as the relationships people maintain with them as sources of life for the living. We must mention a relevant fact. Ritual acts are superior to other reproductive activities for their effects on the collectivity. While men concentrate ritual knowledge and implementation, older women perform secondary tasks, like preparing provisions, playing drums, distributing bua malus, etc. (Traube, 1987:164-6; 222).

When she analyses the distribution of authority and ritual knowledge among the Mambai, Traube states that these were monopolized by men, that is, men of high-ranking houses. They concentrated ritual knowledge and its correct interpretation, which were not democratically shared (Traube, 1987:112-3; 178; 236). Forman (1977) reports the same among the Makassae. It also occurs in matrilineal groups, such as the Wehali Tetum (Therik, 2004), studied between 1992 and 1993, and the Bunak of Lamaknem, Indonesia, studied by Friedberg (1977, 1989) from 1966 to 1973. Among the matrilineal Wehali Tetum and Lamaknem Bunak, women were somewhat less vulnerable, being full members of their mothers' origin house (Friedberg, 1989:549). However, they were not allowed to play the leading role, on an equal footing with men, in rituals related to the relationship with ancestors and colonial agents, although they were deeply involving in preparing those rituals and were the guardians of the sacred houses, as among the Wehali Tetum. Elderly Mambai and Wehali Tetum women attended rituals, but in subaltern positions with no voice.

Notwithstanding, women commonly exerted authority in domestic discussions about rituals, the sealing of alliances, etc. The fact that they did not preside over rituals by no means implies their exclusion from ritual processes. They had a central role in preparation and decision-making. When Hoskins (2012:20) comments on Kodi women's agency in ritual decisions, he shows that, by not participating, they had the right to veto all important decisions about their children's marriage or transmission of property (land, cattle, etc.). She also points out that the women's potential to act upon these matters increased as they grew older. Hence, women's degree of vulnerability has to do with their station in life. Younger, recently married women are more vulnerable and susceptible to exclusion. However, this is also true of many young men.

In the context of Portuguese Timor, according to the sources available, the Caraubalo Tetum ritual practices were an important exception. Their women led parts or the whole of important rituals, like those related to marriage and 
agriculture. However, men commanded funerary and rainmaking rites, the latter performed in sacred places invoking the major mythical ancestors. According to Hicks (1984), male leadership in mortuary rites is due to the fact that these are rituals of separation, which are mostly catalyzed by male forces, as opposed to the conjunctive effects yielded by female forces. Hence, among the southern Tetum, there was an extraordinary attempt to harmonize the sex of the officiating person with the ritual outcome in terms of gender classification: when female potency produced conjunctive results, women led conjunctive rituals; when male potency was associated with disjunctive effects, men conducted rituals of separation.

In Traube's perspective (1987:175-176), the main function of Mambai white rituals was to restore the balance between opposite forces. Ultimately, restoring such balance was their way to secure the fertility of men, women and their world. In those rituals, in more ways than one, men monopolized communication with mystical entities with fertilization powers. Mambai men's protagonism was again evident in the black rituals (lia mate in Tetum), regarded as counter-gifts to various entities, such as Mother Earth. The offering of a new putrefying body would produce fertilization (Traube, 1987:224, 242). Forman (1979:92) identifies a similar way to make sense of these funerary rituals among the Makassae, as does Hicks (1984) about the Caraubalo Tetum.

With the exception of the Caraubalo Tetum, these cases reveal two recurrences among the various Timor-Leste peoples. One is that men and their agency concentrate ritual knowledge and powers that trigger processes of collective fertility. We might say that, when men monopolize certain types of ritual knowledge, they acquire the capacity to produce fertility, thus seizing powers that are proper to women in a biological sense. In other words, what seems to be at stake in these ritual practices is the attribution to men of powers associated with fertility, making it actually more powerful than that of women because it encompasses larger collectivities. In part, this results from the fact that men handle higher dimensions of costume, cultura, tradição, adat. Consequently, they retain the exclusive knowledge of rituals. In monopolizing this knowledge, on which social reproduction depends, men gain fertility and reproductive powers and, thus, divest women of these potencies. It is not accidental that ritual authorities, even males, are classified as females (Errington, 1990:19).

These facts reveal an important disjunction between sex and gender in the ways Timor-Leste peoples perceived and made sense of the world. They employed gender classifications to express higher or lower values in different contexts. Consequently, a male ritual leadership could be classified as female. Friedberg (1977:37-38) put forth this hypothesis when he realized that the Bunaq qualified 
men as pana - a feminine adjective and noun. This is why their category Bein pana ('female Sir') was not contradictory. For the Bunaq, feminine and masculine had symbolic values clearly inspired in male and female features, but did not coincide with a real sexual division. Therefore, the notions of feminine and masculine stood over and above the categories of man and woman.

Concurrently, it seems reasonable to hypothesize that male prominence in higher-level rituals oriented to collective reproduction gave men a capacity for fertilization, conceived as feminine, but no longer associated with women. Based on the information presented above, I argue that to entrust men with powers to activate fertility allows them to occupy a dominant position in the symbolic reproduction of their own group. These procedures empowered them and weakened women's position and status. Here, two Caraubalo Tetum origin myths call our attention (Hicks, 1984:7-13). In both, society comes into being with the theft of women's powers. Hicks interprets men's engagement in bloodletting activities, like cockfights and wrestling, as a symbolic way to acquire fertility powers through contact with animal or human blood.

\section{Marriage prestations and the female condition: an unfinished debate}

As mentioned above, marriage and marriage exchanges are central for how Timor-Leste peoples make sense of the flow of life (Fox, 1980) and for the dynamics of reproduction and production of the world they live in. Life transmission and reproduction take place via the circulation of women between houses. Thus, marriage is how the houses extract female productive and reproductive potential from each other and nurture their alliances.

Given the importance of marriage for the houses' material and moral reproduction, they are regarded as matters of order and collective interest. Among various Timor-Leste peoples, marriages did not pertain to individual wills, but to contextually defined challenges and interests of economic, political and moral order (Carsten \& Hugh-Jones, 1995). This would be yet another way to control women and appropriate their female potential. However, we should note that lack of choice equally affected men. ${ }^{6}$

In the colonial period, the issue of marriage prestations was the object of much political and epistemological anxiety. These appeared in academic anthropological knowledge, in missionary ethnographies and in other colonial knowledge designed to promote social change (Fernandes, 2014a). Given the relevance of this issue, I shall discuss the ways marriage exchanges seemed to affect especially the position of women, depending on the analytical perspective. 
From the viewpoint of the academic discipline of anthropology, marriage prestations consist of the circulation of persons (women in patrilineal, men in matrilineal societies), goods, rights and recognition. They comprise the offering and exchange of various goods in specific moments. Barlake, as it is called in Dili today, is a phase of those exchanges. To Goody (1973), marriage prestations involve the transmission of rights in people and property for various social purposes: economic, political, religious, etc. Their consequences are larger than in a simple exchange. They are complex, highly controlled operations through which people negotiate 1) the right over a woman (or a man) and her offspring; 2) the kinds of duties the couple, their ancestors and descendants will have vis-à-vis their blood and affinal relatives; and 3) inheritance rights. Goody (1973) points out that these rights and duties are negotiated according to: 1) size; 2) use; 3 ) the profile of the givers and takers; 4) content; and 5) potential of return.7

Barnes (1980) explores how, in certain Flores and Timor societies, marriage prestations operated in the choice of membership and residence. He shows that the rules, the ideal models of membership (matrilineal or patrilineal) and residence (virilocal or uxorilocal) did not define the outcome of marriage a priori. The filiation of children - and of the couple themselves - and their rights and duties to their houses were tacitly negotiated during the marriage prestations, taking into account the perspectives of the houses' reproduction.

In general, the anthropological studies carried out between the 1960s and 1970s among different Timor-Leste peoples highlight the central place of marriage exchanges in social reproduction and in alliances. However, they do not address their consequences to the woman's subjectivity. In turn, missionary ethnographies and other discourses by colonial agents took what they called barlake as one of the main factors why women would be treated as subaltern among local peoples. This does not mean, immediately, that marriage exchanges were understood as such by Timor-Leste women. Moreover, the purpose of missionary ethnographies was not to understand the women's point of view. I don't intend to conclude which perspective is correct about barlake and other forms of marriage prestations, for there were various ways women in different positions experienced them.

The exchange of goods between houses and families engaged in giving or taking a wife is the vehicle to transfer rights in persons. This practice has nourished the negative perceptions about marriage exchanges that appeared in part of the missionary studies prior to Vatican Council II and other colonial discourses. They considered it a way to objectify women, turning them into things. They reckoned that women were traded as objects, no matter how exceptional those objects might be, how important they were to seal long-term alliances, and how 
mutual gift exchange could be. With this rationale, an important part of the pre-Vatican II missionary discourses and of other colonial sources suggested that women were bought and sold; therefore, marriage would be a market operation, whose utmost concern would be the material interests of the parties involved.

Polygamy, mostly practiced by high ranking men, was seen as a consequence of marriage prestations. Furthermore, the fact that many marriages were negotiated by the couple's fathers and uncles in the colonial period was interpreted as depriving the woman of her agency, a disrespect for her feelings and choices, which were later called human rights. Supposedly, she would be forced to marry regardless of her will. Indeed, many missionaries and colonial agents considered that, in local marriage practices, disregard for romantic love was demeaning to the woman (Silva, 2015). Customary marriage was thus an affront to women's dignity, because it prevented them from acting as individuals, from freely making their own choices. Due to that perception, marriage prestations became the target of missionary combat until Vatican Council II. From then on, the missionaries showed a more tolerant position (Fernandes, 2014a:94). But, as mentioned in the beginning of this essay, it is not possible to identify women's feelings and attitudes about marriage exchanges in both the anthropological production and the colonial and missionary discourses.

Between 1969 and 1973, an interesting controversy about marriage practices, known as "the barlake war," took place in Dili. The main issue hinged on the most appropriate way to interpret marriage prestations, whether as a market transaction where women were bought and sold, or as an alliance exchange which tied the parties into mutual obligations. The protagonists were Nicolau Lobato, Xavier do Amaral and Abílio Araújo, on the Timor-Leste side, and Jaime Neves, Inácio de Moura and Luis Filipe Thomas, on the Portuguese side. By and large, those on the East Timor side, together with Luis Filipe Thomas, demonstrated that marriage exchanges were not market transactions, but devices through which houses engaged in mutual aid and obligations that were crucial to their material and symbolic reproduction. Hence, it was not the marriage exchanges that oppressed women, but the abuses committed in their name.

According to Luis Filipe Thomaz (Silva, 2018), the main source of potential oppression of women was the effort to maintain the status of the origin houses, which were either reproduced or threatened by marriage strategies. The pursuit of maintenance led to celebrating marriages that did not respect the women's wishes and sentiments. For example, the marriage of persons from houses of different ranks was ill-received. 
Friedberg (1977) shows women were potentially weakened when they had to move to their husbands' villages, especially when these were distant from their original villages. Recently married women suffered because affective ties with their families would be abruptly severed.

\section{The Catholic Church and the making of Timor-Leste women}

As we know, the Catholic Church was of utmost importance in the colonization of Portuguese Timor. The relations between State and Church changed through time, due to changes in metropolitan policies. Nevertheless, the Catholic Church and its members remained as very important figures in remodeling the world views and ways of life of Timor-Leste peoples. To Christianize local populations, the Church installed mission stations throughout the country. In 1949, the Dili Dioceses responded for 54 stations. These comprised schools, churches, missionaries' houses, workshops, small and large farms (Rego, 1961 apud Fernandes, 2014a). The following map shows the location of the mission stations in Portuguese Timor in 1965:

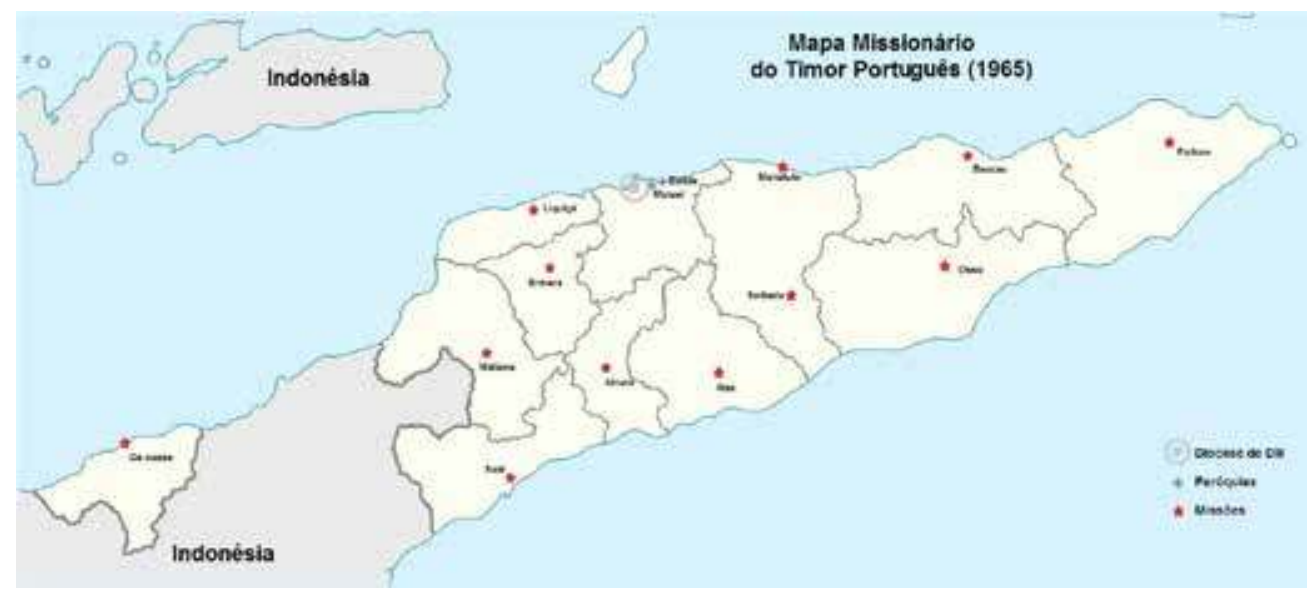

Source: Fernandes (2014a:24).

At first, Timor-Leste women became the target of the Catholic Church in a residual manner, as it were. The Church realized that to be successful in producing Christian men, they needed Christian women (Fernandes, 2014a). To this end, the Church summoned the Canossians, a female religious order devoted to women. Of similar persuasion, Carmelites and Dominicans came later to Timor-Leste (Tchailoro, 2016).

According to Brito (2012) and Ximenes Belo (apud Tchailoro, 2016), the Canossians began their work in Dili, where they established a boarding school for girls (Colegio de Santa Julia e Sáo José) in late nineteenth century. They 
also taught in three public schools and at the Casa do Colégio Montael (1880) and in Bidau (1890). Still according to Brito, the Cassonians provided a formal education dedicated to lay instruction (to read and write) and informal, religious learning. Timorese girls would be apt as wives in Christian homes, with Western abilities, such as cleaning, sewing, embroidering and weaving. The production of Christian women at Canossian institutions, between the late nineteenth and early twentieth century, was recently described as follows:

in all their houses, the nuns taught [the girls] sewing, household chores, fancy needlepoint in gold, flower making, never neglecting to induce in the girls a perfect notion of their social and domestic duties and instill in them working habits in harmony with the condition of a Timorese woman. Moreover, give them a solid religious education (O expulso de Timor, 2009:3).

In time, the number of Canossian institutions in Portuguese Timor increased. Just before World War II, the Canossian mission "had three houses with three schools with about 200 students in boarding schools and around 300 in daytime schools" (Naroman Foun, 2009:4). Between 1879 and 1973, 68 Canossian nuns, many of them Italian, went to Portuguese Timor (Fernandes, 2014b).

After 1940, the Missionary Agreement between the Vatican and Portugal and the agendas of the State and the Catholic Church came closer together both in Timor and in the other colonies. As a result, producing Christians was part of the process of producing Portuguese citizens and vice-versa (Fernandes, 2014a). This helped to approximate the social agendas of the Church and the State in Timor-Leste. In the 1960s, public school curricula in the Portuguese colonies had a civilizing agenda geared toward women, which was very similar to that of the religious schools.

The 1966 curricula framing women's education aimed at making wives, mothers and homemakers in the mold of the Portuguese. It meant teaching them housekeeping, cooking, sewing and family education. Cristalis and Scott (2005, 23-25), who report similar facts, suggest, moreover, that the Catholic education of Timor elite women, to the extent that it accentuated their role in the domestic sphere, may have contributed to reinforce their exclusion from public spaces and institutions where collective life has been negotiated. We should also point out that it was mainly high-ranking women who had access to schooling. Nevertheless, subversion was always possible. For example, in Timor-Leste public space, persons like Sister Guilhermina Marçal and Maria Domingas Alvez were educated in Christian institutions that favoured women's political affirmation. Against all expectations, the benefits of their learning in Catholic institutions served to empower women in public spaces today. 


\section{Final considerations}

As the title of this essay suggests, my purpose is to systematize a set of reading notes to further the debate about women's conditions in Portuguese Timor from 1945 to 1975 . My arguments are still necessarily provisional, bound to be revised. Inspired by Strathern (1988), I place my interpretations between anthropology and feminist critique. From the anthropological point of view, I position women's subalternity in collective and public spaces as a result of the characteristics of the institutions to which they belonged, mostly houses and their alliance dynamics. From the feminist perspective, I have tried to underline how certain features of the local social organisation and its dynamics - especially in patrilineal societies - favour men's interests in collective life. We should not forget, however, that men and women share sociality expectations to a large extent. It is not by chance that, in the past as in the present, marriage prestations were crucial to uphold the dignity of both men and women, despite the various political attempts to extinguish them.

I briefly hypothesize that the women's transitory membership in their groups of origin (houses) and in those of their husbands, together with the value placed on fixedness, contributed to diminish women's power in collective spaces. Because of their transient or impermanent ties to their parents' and husbands' groups, women and their interests were relatively excluded from the institutions that govern society. These same constraints curtailed, among other things, their access to inheritance. The institutions that managed collective life seem to always be geared to men's interests. Men often monopolized the institutions that comprise kultura, that is, usos e costumes. Women seemed to be less vulnerable in matrilineal groups. However, even there they were in a subaltern position, because men control culture-oriented institutions. I thus show that the rituals reinforced male dominance in the management and reproduction of collective life.

At the present stage of our knowledge about gender dynamics in Timor-Leste, my main contribution here is the analysis of certain ritual practices that endow men with powers of collective fertilization. These powers pertain to the domain of custom, tradition and kultura, a supposedly sacred and immutable realm monopolized by men.

In parts of this critique, I have also underlined the need to take into account that women's power positions changed over their lifetimes. This occurred because, among Timor-Leste peoples, generation hierarchies were even stronger than gender ideologies in the making of local systems of prestige. This is equally true in the whole of Eastern Indonesia (Errington, 1990). Moreover, we must recognise that the conditions in which women participate in institutions that manage collective 
life also depend on their groups of origin. About these analytical complexities, says Errington (1990:7):

[...] in hierarchical societies of Southeast Asia, it is very clear that women who are of high status by birth outrank men who are of low status by birth, whether by material or symbolic criteria; moreover, in many societies, among them quite a few in island Southeast Asia, a woman acting in the capacity of a sister is quite different for social purposes from a woman acting in the capacity of a wife. In either case, it is difficult to conceptualize "the" status of women in such a society, or to imagine what their collective interests might be in relation to the opposing category, men.

At any rate, it is important to point out again that the anthropological and missionary works on the region paid little analytical attention to the position of real women in the dynamics of social reproduction and never reported their own perception about these issues.

Analyzing the literature dedicated to recover the history of colonialism in Portuguese Timor teaches us that the controversies around marriage prestations and women's conditions in that country are complex, lasted long and changed in time. It also suggests that Western-oriented education of women, to the extent that it stressed their role as mothers and wives, may have contributed to reinforce their exclusion from the public institutions in charge of collective life.

Finally, I would like to call attention to the partial character of my analyses and point at some issues that require more attention to elicit further knowledge on Timor-Leste by the social sciences. We need this if we are to have a more accurate notion of how the women felt about the dynamics of social reproduction that encompassed them: where is the domestic space and its attendant activities placed in the local prestige systems? How do distinct social collectivities value women's activities? What is men's participation in activities hegemonically carried out by women? Are women thought of as alienable or inalienable by their groups of origin? How is the female condition perceived vis-à-vis other valuable objects that circulate at marriage prestations? How do people allocate responsibility and causality to facts related to what we call agency and power of men and women? Do agency and power necessarily relate to dominance? How do several men and women act upon each other, produce effects and make sense of them?

Submitted on 10/01/2015

Accepted on 21/03/2016 
Kelly Cristiane da Silva is an associate professor at Universidade de Brasília and a researcher fellow of the National Council of Science and Technology (CNPq). As she concluded this article, she was also a visiting researcher at Universidade de Lisboa. She is the leading researcher of the research group "Processos de invenção, transposição e subversão da modernidade”. Contato: kellysa67@gmail.com.

\section{Notes}

1. This article answers the request by the Committee on Research and HistoryMaking of Women's Struggle in Timor (Comissão de Pesquisa e Elaboração da História da Luta da Mulher em Timor). It was supported by the Brazilian National Council for Scientific and Technological Development through the Project on Gender, Justice and Violence: a Comparative Perspective on Citizenship Dilemmas (482119/20136), coordinated by Daniel S. Simião, Renata da Silva Nogueira and Alexandre J.M. Fernandes, Ph. D. candidates of the Department of Anthropology, University of Brasilia, and Andreza Ferreira, post-graduate student at the same institution, collaborated with data organisation, as did Yu Zhiming, a Master's candidate at the Geneve Graduate Institute. I thank them for their commitment and intellectual sharing. I am also very grateful to Sara Niner for her attentive critique to an early version of this article.

2. For a description of the anthropological production in that period, see Hicks (2011). Unfortunately, I had no access to the work of Maria Olimpia Lameiras Campagnolo, unavailable at the libraries I consulted.

3. For a discussion about politics of gender in contemporary Timor-Leste, see the various essays published in Niner (2017).

4. The original version of this essay had a section on women's sexual slavery during Japanese occupation. I removed it so as to highlight the condition of women in postWorld War II.

5. However, we notice that, among some groups, membership in a house is not given by birth, even for men, as among the Caraubalo Tetum studied by Hicks (Barnes, 1980).

6. Until recently, women could not choose their spouses. This choice was made by her father or uncles who considered the interests of their house regarding its reproduction. Very often, women experience lack of power to choose as suppression of agency. However, we cannot affirm that it was always so, in so far as cultivating and perceiving the individual right of choice is also a cultural fact.

7. In his monograph, Renard-Clamagirand (apud Barnes, 1980) indicates two kinds of marriage prestation among the Timor Ema: the small and the big "price." Each one had distinct implications connected to the descendants' filiation, the ties of man and wife to their ritual houses etc. Among other things, marriages mediated with a small price meant the possibility of divorce and the division of the offspring between both houses. When the big price was paid, this was no longer possible. The woman was 
thoroughly tied to her husband's lineage and could not return to her village, even if she became a widow. Nor was divorce tolerated. The woman was ritually severed from her ancestors. In this type of marriage, the woman could take with her a dowry in jewels and even a piece of arable land. Marriage began with a series of prestations between the houses involved, implying, among other things, the possibility that lineages facing extinction could receive the children of their women givers and takers. This happened mostly with elite lineages. The gift of a child increased the status of its lineage of origin and was carried out with a counter prestation of certain crafts and animals.

\section{References}

BARNES, Robert H. 1980. "Marriage, exchange and the meaning of corporations in Eastern Indonesia”. In: John L. Comaroff (ed.). The meaning of marriage payments. New York: Academic Press.

BRITO, Ervinia M. 2012. A proposta educacional da congregação canossiana em TimorLeste. Dissertação de mestrado, Universidade de São Paulo.

CARSTEN, Janet \& HUGH-JONES, Stephen. 1995. "Introduction". In: About the house: Lévi-Strauss and beyond. [S.1]: Cambridge University Press.

CRISTALIS, Irena \& SCOTT, Catherine. 2005. Independent women: the story of women's activism in East Timor. London: Ed. Catholic Institute for International Relations.

ERRINGTON, Shelly. 1990. "Recasting sex, gender and power: a theoretical and regional overview." In: Jane Atkinson \& Shelly Errington (eds.). Power and difference: gender in Island Southeast Asia. Stanford: Stanford University Press.

FERNANDES, Alexandre J. M. 2014a. Em searas do Timor Português: um estudo sobre as práticas de mediação da Diocese de Díli no período colonial (1949-1973). Dissertação de mestrado, Universidade de Brasília.

. 2014b. Sobre os impactos dos colonizadores nas relaçôes de gênero. Working Paper presented to the Research Seminars on the Condition of Women in Portuguese Timor.

FORMAN, Shepard. 1977. "Exchange and political hierarchy at the time of the European discoveries". In: Karl L. Hutterer (ed.). Economic exchange and social interaction in Southeast Asia. Ann Arbor: University of Michigan. pp. 97-111.

FOX, James. 1980. "Introduction". In: (ed.). The flow of life: essays in Eastern Indonesia. Cambridge: Harvard University Press. pp. 11-18.

FOX, James. 1996. “Introduction”. In: James Fox \& Clifford Sather (eds.). Origins, ancestry and alliance: explorations in Austronesian ethonography. Canberra: ANU E-Press. pp. $1-18$. 
FRIEDBERG, Claudine. 1977. "La femme et le féminin chez les Bunaq du centre de Timor”. Archipel, 13:37-52.

. 1989. "Social relations of territorial management in light of Bunaq farming rituals." Bijdragen tot de Taal, Land en Volkenkunde Deel 145, 4. Rituals and SocioCosmic Order in Eastern Indonesian Societies. Part I Nusa Tenggara Timur. pp. 548-563.

GODELIER, Maurice. 1982. La production des grand homes. Paris: Librarie Arthéme Fayard.

GOODY, Jack. 1973. "Bridewealth and Dowry in Africa and Euroasia”. In: Jack Goody \& Stanley J. Tambiah. Bridewealth and Dowry. Cambridge: Cambridge University Press.

HICKS, David. 1984. A maternal religion: the role of women in Tetum myth and ritual. North Illinois University Press.

Waveland.

2004. Tetum ghosts \& kin: fertility and gender in East Timor. Long Grove: . 2011. "A pesquisa etnográfica no Timor Português". In: Kelly Silva \& Lúcio Sousa (eds.). Ita maun alin: o livro do irmão mais novo. Afinidades antropológicas em torno de Timor-Leste. Lisbon: Colibri.

HOSKINS, J. 2004. "Slaves, brides and other 'gifts': resistance, marriage and rank in Eastern Indonesia". Slavery \& Abolition: a Journal of Slave and Post-Slave Studies, 25(2):90-107.

Routledge.

2012. Biographical objects: how things tell the stories of people's life. New York:

KAMMEN, Douglas. 2012. "Queens of Timor”. Archipel, 84:149-173.

LÉVI-STRAUSS, Claude. 1983. The way of the masks. London: Jonathan Cape.

McKINNON, Susan. 1991. From a shattered sun: hierarchy, gender and alliance in the Tanimbar islands. Madison: University of Wisconsin Press.

NINER, Sara. 2012. "Barlake: an exploration of marriage practices and issues of women's status in Timor-Leste”. Loca-Global: Identity, Security, Community, 11:138-153. 2017. Women and the politics of gender in Post-Conflict Timor-Leste. Between Heaven and Earth. New York: Routledge.

NOGUEIRA, Renata S. 2014. "A posição cambiável física e simbólica das mulheres: uma reflexão sobre poder, gênero e mulheres em Timor-Leste”. Working Paper presented to the Research Seminars on the Condition of Women in Portuguese Timor. 
ORTNER, Sherry B. 1974. "Is female to male as nature to culture?" In: Michelle Z. Rosaldo \& Louise Lamphere (eds.). Women, culture and society. Stanford: Stanford University Press.

RUBIN, Gayle. 1975. "Traffic in women: notes on the political economy of sex". In: Reiter Rayna (ed.). Toward an anthropology of women. New York: Monthly Review Press.

SILVA, Kelly. 2015. "Marriage exchanges, colonial fantasies and the production of East Timor indigenous socialities in the 1970s Dili". In: Leach et al. Understanding TimorLeste. Díli: v. II, pp. 228-233.

. 2018. "The 'barlake war': marriage exchanges, colonial fantasies and the production of East Timorese people in the 1970s Dili”. In: Ricardo Roque \& Elizabeth Traube. (ed.). The colonial archive: crossing histories and ethnographies. London: Berghahn. In press.

STRATHERN, Marilyn. 1984. "Subject or object? Women and the circulation of valuables in Highlands New Guinea”. In: Renée Hirschon (ed.). Women and property, women as property. London: Croom Helm. pp. 159-175.

. 1987. "Introduction". In: . (ed.). Dealing with inequality: analysing gender relations in Melanesia and beyond. Cambridge: Cambridge University Press.

. 1988. The gender of the gift: problems with women and problems with society in Melanesia. Berkeley: University of California Press.

TCHAILORO, Nuno R. 2016. Relijioza Sira Nia Luta ba Ukun Rasik. Dili: Mimeo.

THERIK, Tom. 2004. Wehali: the female land. Traditions of a Timorese cultural centre. Canberra: Pandanus Books \& Australian National University.

TRAUBE, Elizabeth. 1987. Cosmology and social life: ritual exchange among the Mambai of East Timor. Chicago: University of Chicago Press.

VAN WOUDEN, Franciscus Antonius E. 1968. Types of social structure in Eastern Indonesia. Haia: Martinus Nijhoff. Publicado originalmente em 1935.

\section{Primary Sources}

MINISTÉRIO DO ULTRAMAR. 1966. O ensino no ultramar. Lisboa: Agência Geral do Ultramar.

Naroman Foun. 2009. Edisaum especial.

O expulso de Timor. 2009. Naroman Foun. Edisaum especial. 


\section{Abstract}

This essay examines the social position of women and the implications of gender representations among indigenous peoples in post-World War II Portuguese Timor. It is a bibliographic critique based on works of academic anthropology and of certain missionary and colonial administrative ethnographies published between the 1950s and 1980s. I argue that in general women occupied a relatively subaltern position in the collective dynamics of social reproduction. This results from the specificity of local social structures and from the separation of sex and gender. I attempt to elucidate an apparent contradiction: on the one hand, femaleness, as a gender classifying principle, is associated with superiority among many peoples in Timor-Leste and, on the other hand, women are often in subaltern positions regarding collective reproduction. I argue that the ways the female principle and the idea of fertility are ritually handled serve the purpose of producing and reproducing male dominance in the dynamics of collective social reproduction and the co-opting of women's power of giving life.

Key-words: women, gender, power, marriage exchanges, Timor-Leste. 